\title{
19TH CENTURY SALT BATHS OF TRANSYLVANIA
}

\author{
KOVACS FERENC \\ University of Arts, Romania
}

\begin{abstract}
The cultural concept called the Salt Road is closely related to the connection between salt and salt mining throughout their multimillenary historical development in view of the economic, demographic and territorial impact on the settlements, in comparison with the revenue resulted from the exploited amount of salt and the earned income, to which the hydropathic character is added during the 19th century, which transforms and freshens the cultural tradition of the use of salt in the development of the settlements. The Romanian research remained due to the elaboration of a detailed analysis of the historical, vernacular and vacationer architectural patrimony. The spa-oriented feature had become part of an extended tendency aimed at enhancing the value of existent spa resources in Transylvania and Europe in the late 19th century. The endeavour to turn to good account the balneary potential in Transylvania used to be productive and attractive in its early days and the importance of the spas was significant and beneficial to the inhabitants. The awareness and deep insight into the past through the promotion and presentation of its history are intended, not only in order to protect the originality and peculiarity of the cultural and historical site, but also to inspire future generations

Keywords: salt, salt mining, salt road, Transylvania, hydropathic baths, settlement growth, cultural identity, local and regional heritage, history, vernacular architecture.
\end{abstract}

\section{INTRODUCTION}

To begin with, the author can speak neither about salt-generated hydropathic resorts, nor of the importance of salt in the development of human communities, even more within those settlements that developed salt resorts before a brief presentation of their evolution is made.

This study represents a small summarized part of a larger doctoral research thesis undertaken by the author, which depicts aspects of the spa resorts origins analysed from the perspective of the mining and of the Salt Road development. This aspects and connections have never been made in Romanian studies until now and this is the first attempt to coagulate different fields into a larger cultural concept in which both salt exploitations and salt spas can be merged under the newly developed cultural heritage concept of the Transylvanian Salt Road. Another goal of the paper is to detect and present elements that can be introduced in this concept as well to identify a common style in the architecture of salt spas. For the development the Salt Road cultural heritage concept it was necessary to investigate the history of localities in study as well as the history of Europe. This information was correlated and overlapped with the topographical maps of the region for the urban planning analysis.

A brief look at the evolution of human civilization enables us to ascertain the major importance that salt has had in the economic and social development of communities. In Transylvania, salt was the warm blood that maintained the life in these places. Europe is the richest continent in salt deposits and the Romanian Carpathian area has represented the "Europe's salt-cellar" for ages [1].

Thus, salt has had an important role over time, both in trade and in "maintaining good health and, in places where it comes in contact with natural water springs, spa baths with therapeutic purposes emerge, baths which served in those old times the needs of people with varied ailments and brought over many foreign tourists" [2].

Following the trends of the age in Europe, in the middle of the 19th century, the valorisation of the sites with a balneary potential in Transylvania began and new balneary 
resorts, which became famous in the following century, were founded: Sovata, Ocna Sibiului, Ocna Mures, Corund, Turda, Cojocna, Sangeorgiu de Mures, Jabenita, Bazna. But their true valorisation was only accomplished towards the end of the 19th and the beginning of the 20th centuries, when the first modern treatment facilities, as well as the related accommodation spaces, such as villas and hotels, were built [3].

During the 19th century and the turn of the twentieth century, many specialists carried out extensive studies on mineral waters, spa resorts and salt exploitations in the research area.

Spengler Oswald mentioned: "The evolved man is a city-builder animal. Universal history is the history of the urban man. People, states, politics and religions, all arts and sciences are based on the only form of archaic human existence: the city" [4]. Each city has its own history, at the same time, its membership in certain conceptual categories is obvious.

As a result of the undertaken observations and research it can be concluded that many establishments, considered architectural masterpieces of the time, are in an advanced state of degradation. Considering that "modern times take their toll on old cities, often erasing, changing or altering them, yet always keeping old elements worthy of attention" [5], it is necessary to point out that the disappearance of any element in the original aspect of any spa compound leads to the extinction of a remarkable witness to former spa resorts.

The constructive and plastic experience accumulated within such programs turns into an advantage for architecture, as a whole, and, consequently, it plays a major role in the history of architecture [6].

\section{SALT AND THE DEVELOPMENT OF THE SALT ROAD}

Salt dependence is physiological, and the flexibility in using it throughout history has made it one of the most valuable and rare products. The history of salt mining has overlapped the history of human civilization since times immemorial. "If there is no salt, there is no human life and, of course, no history and historians, linguistics and linguists" [7].

"Salt is one of the factors that facilitated the emergence of settlements, therefore its history merges with the history of the great civilizations, since, around salt mining areas, important human agglomerations were formed" [8]. These are the core of the concept of Salt Road, since the multimilenary existence of the localities in which salt is exploited, is the one that generates other cultural elements.

The presence of easily exploitable salt in various forms was a key element in the process of sedentarization, being later exploited by local communities as a factor in stimulating the development of localities. The lack of salt in the neighbouring territories gave rise to the early salt roads, through which this vital resource was traded in more distant territories.

The amplitude of salt exploitation and trade had been definitively changed and developed to another level during the Roman occupation in Transylvania, when salt was exploited in all the areas where it was discovered. Roman administration being the one that established and initiated the Salt Road.

The spas in Sovata, Ocna Sibiului, Turda, Ocna Mures have their origin, to a certain extent, in this period, and the continuous salt exploitation until the 19th century created the perfect framework for the use of the former mines, of the salt and water in these places as a balneary resource.

Thus, centuries of exploitation brought about, besides numerous economic benefits, a less intentional component, salty lakes. Within the studied areas there are fewer natural lakes than those that formed on the site of former exploitation.

This is mainly due to the method of exploitation within the first centuries of existence of localities. The Romans, who exploited salt from Transylvania on an industrial scale, 
performed it at the surface. This is how, among others, the Roman Lake in Turda, Horia, Cloşca and Crişan lakes in Ocna Sibiu or the Black Lake in Sovata came into existence.

Starting with the Middle Ages, cone-shaped mines spawned other salty lakes with a smaller area, yet much deeper, such as those in Cojocna or some in Ocna Sibiu.

The natural lakes appear due to the infiltration of underground water, which erodes the salt mountain, forming sinkholes whose ceiling collapses. (ex. Ursu Lake in Sovata).

These lakes, alongside the salt springs, facilitate the development of spa resorts, which, in some cases, after the exploitation had been closed, continued to maintain a prosperous community and, at the same time, extended the Salt Road concept all the way through to the modern period (Fig. 1).

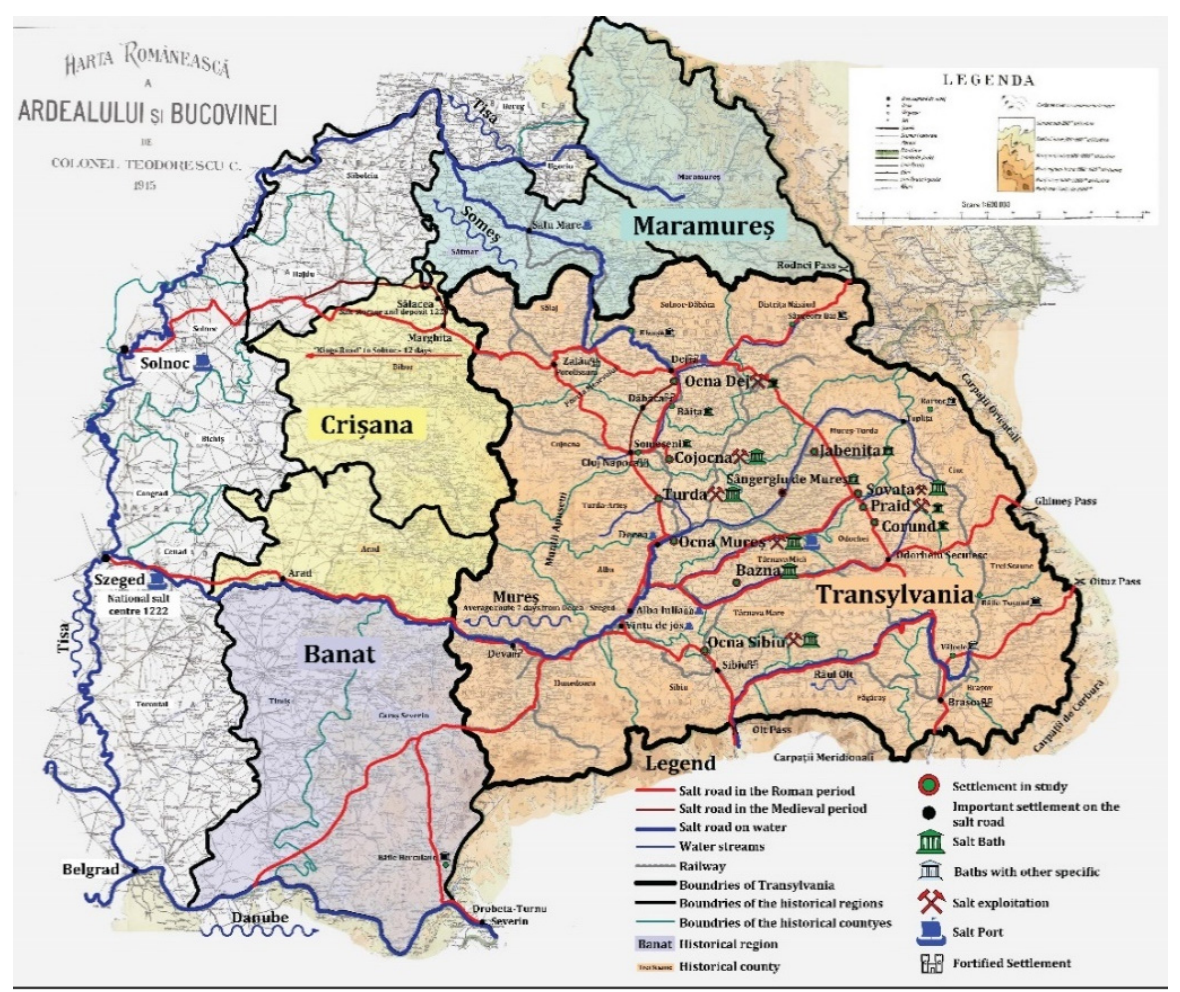

Figure 1: Salt Road on the Romanian Map of Ardeal and Bucovina from 1915.

\section{IMPACT OF SALT EXPLOITATION ON THE BALNEARY CHARACTERISTIC OF THE LOCALITIES}

The urban development of the studied localities from 1790 to 1950 results from the analysis of the Austrian, Hungarian and Romanian topographical maps. These historical maps are public and can be found in web application transposed over the OpenStreetMaps maps.

Thus, three Austrian military maps from 1763 to 1887, two Hungarian military maps from 1869 to 1941 and Romanian maps of the 1950s were analysed. In these analyses, it can be noticed the development of the land strip maps, spa areas and mining areas alongside sketches of spas and salt mines (Figs 2 and 3). As a final reference in this process, the author synthesized the information on the projection system maps of 1950 (Fig. 4). 


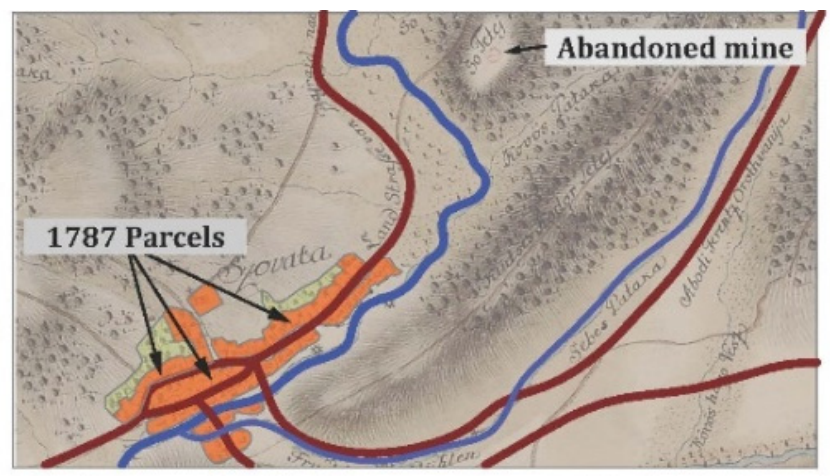

Figure 2: Military map of Sovata, 1763-1787.

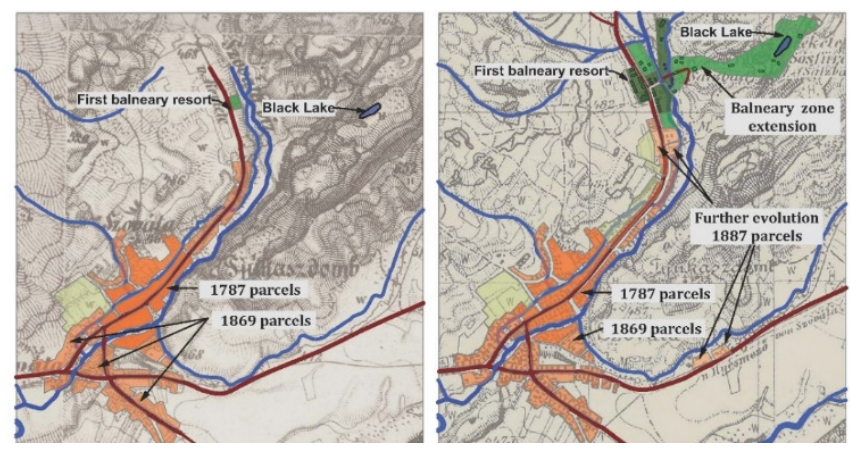

Figure 3: 1806-1869 and 1869-1887 Military maps of Sovata.

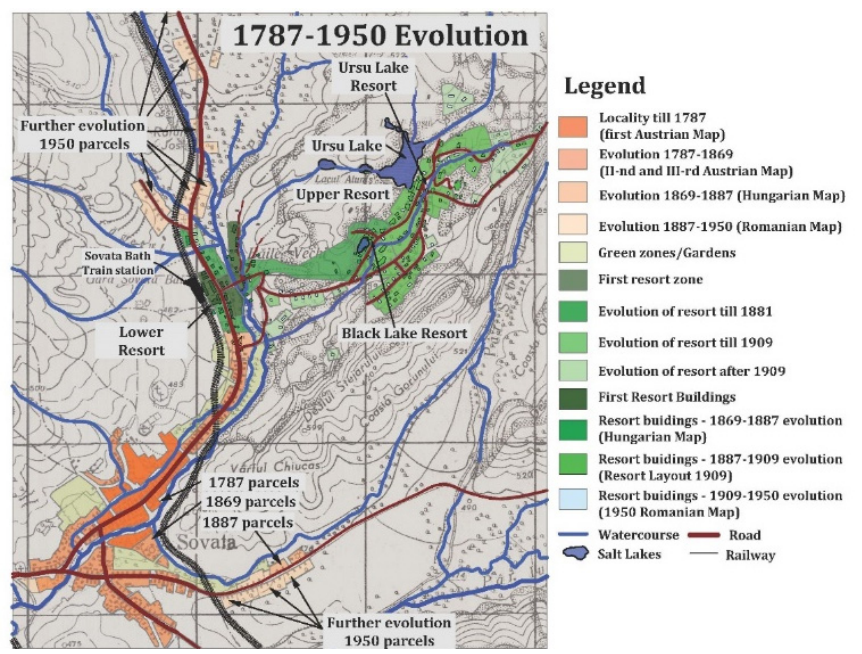

Figure 4: Romanian map of Sovata, 1950. 
Abroad "there are interesting studies about the connection between the development of the resorts and the evolution of the traffic routes, according to which, the development of the resorts depends on the development of the railway networks and roads. As for the connection between roads and railways the situation is different in Romania since there are no train station in many resorts" [9]. In the case of Transylvania, however, it can be noticed that the resorts are indeed influenced by the introduction of the railway. Yet, their successful development is not exclusively due to the existence of the stations because the height in their popularity takes place long after that moment.

The 19th century was characterized by a rapid development, resulting in a well-organized network of baths in the early decades of the twentieth century [10].

Spas have contributed to the appearance and development of localities, primarily due to the buildings that were to accommodate tourists, to those in which treatment was carried out, as well as to the bath pavilions and constructions around the mineral water springs [11].

\section{SPA RESORTS IN TRANSYLVANIA}

The culture of the spas is one of the earliest cultural possessions, and its manifestations, in terms of the historical period and the geographical areas, are extremely diversified. Thus, spa culture is often specific to a particular civilization [11].

Visiting baths also demonstrates the appearance and development of a new rhythm of life. In the balneology books of the time, the best way to maintain health was bath taking.

On the other hand, "attending the baths in the big cosmopolitan resorts bears an educational component that should not be overlooked. To be accepted in the society of a large international resort meant to demonstrate that you managed the many and complicated rules that governed it: one had to know the art of conversation, dance, dress codes, etc." [9].

The emergence of spa resort location is closely related to the industrial area of salt exploitation. The bath pavilion used to be located in the vicinity of the spring or former salt mine, being the most important building of the spa and offering a wide range of tourist services.

In the case of Ocna Mureş (Fig. 5 right), the resort appears in the immediate vicinity of the mining area and the city centre, on the site of former meanders of the Mureş River, which had been systematized to protect the salt exploitation. The location of the resort near the mining area was necessary because there were no lakes and the salty water had to be drained from underground and pumped into the pools. The connection between the spa and the mining areas, respectively the city centre, is made by means of the park of the resort, offering the inhabitants an accessible leisure and promenade area.
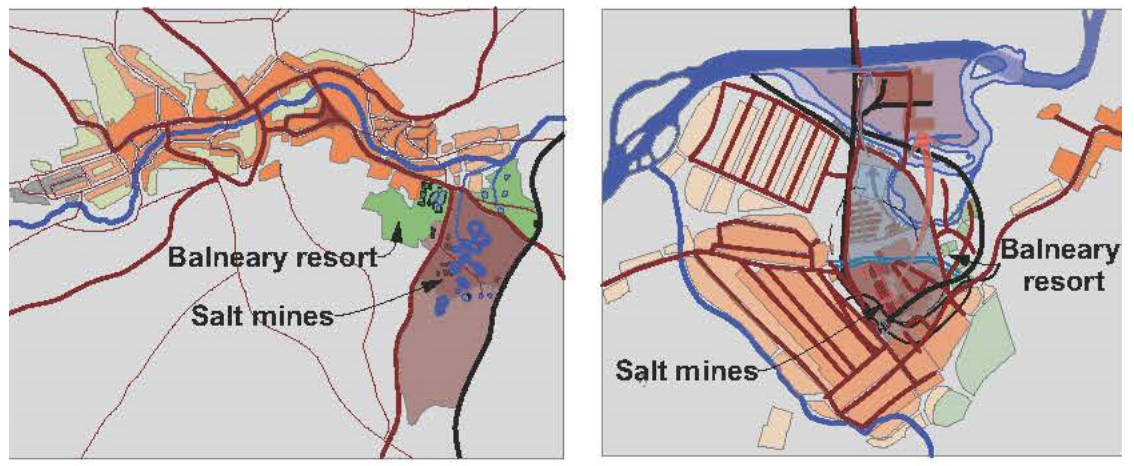

Figure 5: Ocna Sibiu and Ocna Mureș, 1950. 
In Turda (Fig. 6, left) there are two areas of exploitation that turned into salty lakes. The first one is on the site of a Roman exploitation in the northeast, where the first spa resort was built. The second spa area develops during the interwar period, to the north of the locality in the Durgău area, simultaneously with the closing of a neighbouring mine, which had existed on the site of old medieval salt pit. Both spa areas are located in the suburbs of the city and the development of the locality is more evident in the area of the Roman lakes. This area turns, due to the resort and parks, into a large leisure area.
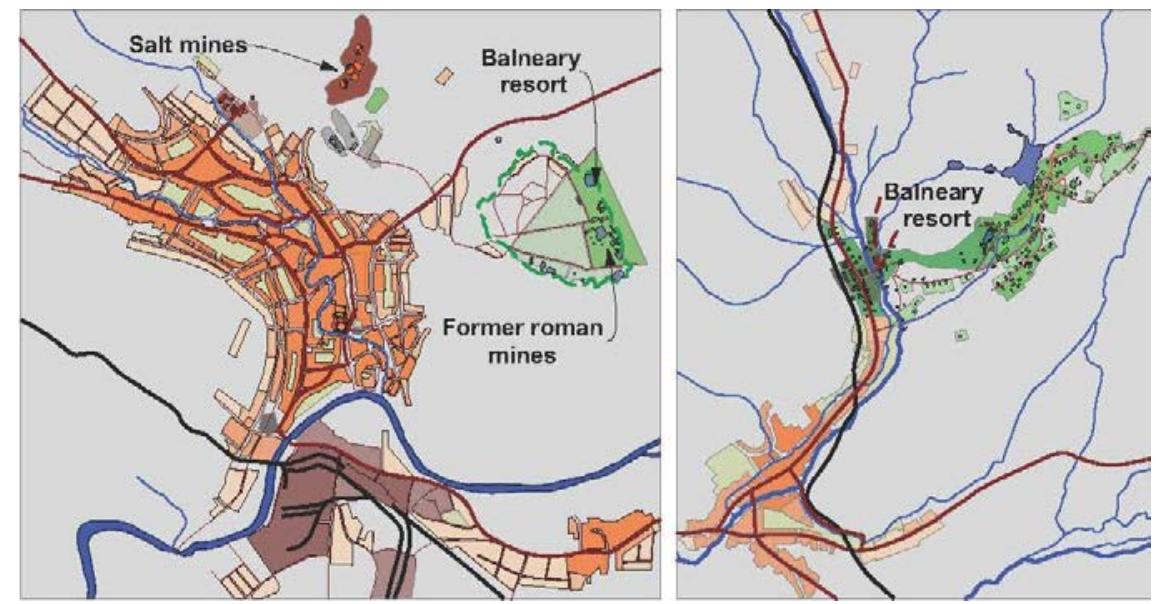

Figure 6: Turda and Sovata, 1950.

Without any doubt, the most spectacular development of the balneary area took place in Sovata (Figs 2, 3, 4 and 6, right), where the area of the town doubled, and it also had a great impact on the number of the inhabitants, a number which became six times larger since the first developments. The impact of the resort is significant both in town-planning and financial terms, making it the main economic "engine" of the locality. A major town-planning impact of the resort on the locality can be seen in Bazna (Fig. 8, right), too.
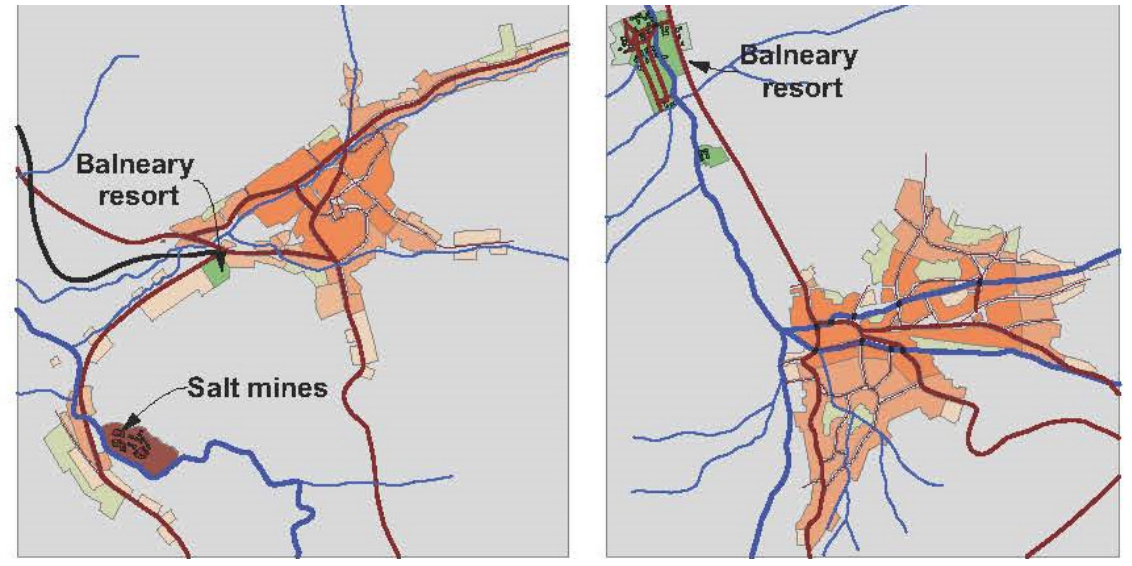

Figure 7: Praid and Corund, 1950. 
In the case of Ocna Sibiu (Fig. 5, left), the presence of the mining and balneary functions has a direct impact on the locality, both financially, through the revenue, and from the town-planning point of view, through the emergence of an extended leisure area. Simultaneously with the industrial area of salt exploitation, the spa resort develops rapidly, and, due to the investments, the number of tourists grows and outnumbers the inhabitants.

In Corund (Fig. 7, left), Jabeniţa (Fig. 7, center), Sângeorgiu de Mureş (Fig. 9, right) and Cojocna (Fig. 9, left), the resorts being smaller in size, had a lesser urban impact than the other localities. From a financial point of view, the resort in Cojocna stands out and the large number of tourists makes us conclude that the impact on the economic development of the locality is much more significant.
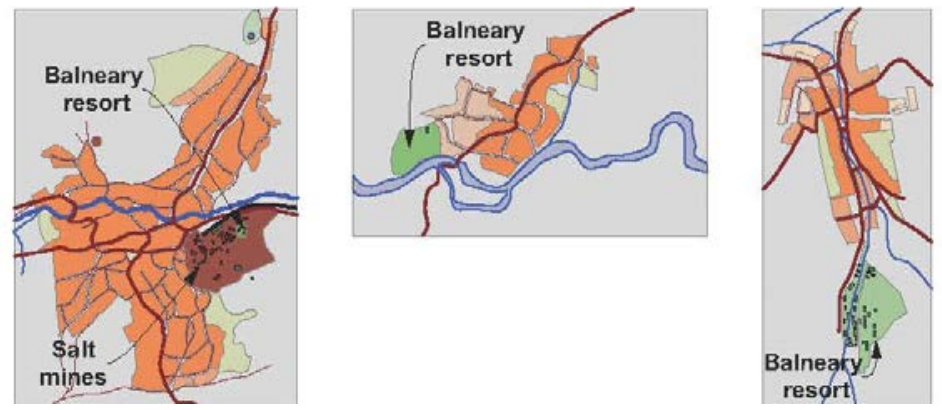

Figure 8: Ocna Dej, Jabenița and Bazna, 1950.
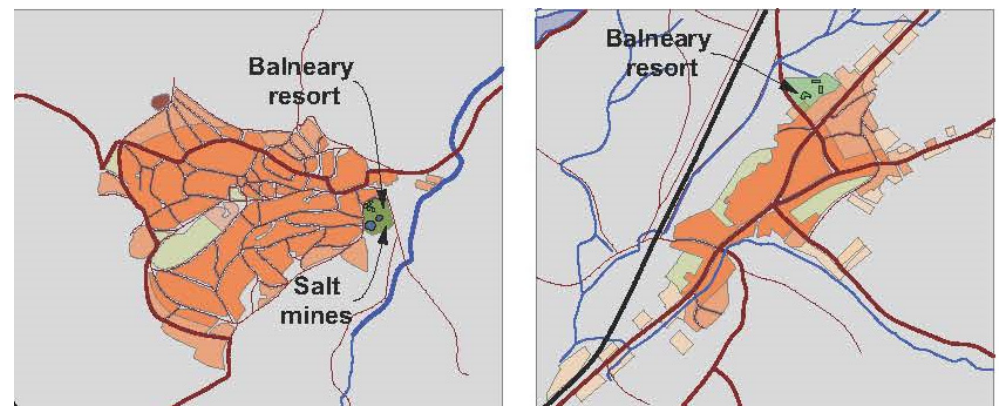

Figure 9: Cojocna, Sângeorgiu de Mureș, 1950.

On the other hand, in Turda and Ocna Mureş, which had a well-exploited and developed spa potential at the turn of the 20th century, there are other factors that contributed to their progress: the development of the industry in Turda and, in the case of Ocna Mureş (besides industrialization), the salt exploitation is increasing, consequently the locality became the most important salt mining area in Transylvania.

The development of Ocna Dej (Fig. 8, left) and Praid (Fig. 7, left) localities is generated by the existing salt exploitations here, the balneary character being a less important aspect in the studied period, but subsequently valorised.

There is a continuous process of transformation of former mines into salty lakes. All salt mining, sooner or later, got to achieve balneary potential. The results of the presented studies 
show that in Ocna Sibiului, Sovata, Cojocna, Bazna, Jabeniţa and Sângeorgiu de Mureş, the resort is the element that defines the locality and sets its development starting with the second half of the 19th century.

As for other spa resorts in Transylvania, during the studied period, many localities enhance their touristic potential according to their specificity, initially offering inspirational models to and competitivity with salt-generated resorts, only to be eventually surpassed in popularity by the latter. This way salt-generated resorts become examples for the rest of the resorts.

Regarding the correlation between the studied resorts and the evolution of the number of visitors, it can be asserted that the peak development of the resorts ("the golden age") takes place between 1890 and 1914. Even though this period overlaps the second wave of urbanization and industrialization, the steady demographic growth during the golden age is largely due to the existence of the resorts in the settlements. This age of prosperity stands out and its consolidation in history is due to the global context of the following decades. Thus, since the First World War, the population was deprived of both material resources and the leisure time needed for spa holidays [12].

In the interwar period, despite the fact that the modernization process continued, some resorts fell into decline, becoming resorts of local interest, and others, such as Sovata or Bazna, continued to enjoy the same popularity, slightly diminished, though. After 1945, this development is even more uneven, and despite large hotels having been built, most of the construction heritage and natural environment was deteriorated [12].

\section{RESORT ARCHITECTURE}

The main architectural styles are reflected in the spa resorts buildings under study. In this study historical images were analysed and compared to what's left today.

Considering the characteristics of the folk architecture in the countryside, being adapted to the conditions of the geographical environment, they are a good example for the construction of buildings in hilly or mountainous resorts. The number of native craftsmen is not enough, therefore, architects from other countries, where the Romantic style is widely spread, are employed. In the sixth decade of the 19th century, the architectural forms of an integral romanticism materialized [13]. Romanticism is gradually abandoned in the late quarter of the 19th century [13], yet, its traces are still visible in the early twentieth century.

In Transylvania, the 1900 style is secession-oriented, the Romanian motifs of folk inspiration are intertwined with the Hungarian ones and generate the neo-Hungarian architecture [14]. By Kós Károly in 1907, the authenticity of the Transylvanian culture is more obvious than in any other part of Hungary, due to the mixture of ethnicities [15].

Within this study two types of building typologies stand out, those for salt exploitation and those for balneary and touristic.

The salt-based resort has four interconnected and partly overlapping functions: treatment, leisure, accommodation and public catering. Of the buildings exclusively designed for spa treatment are the buildings that house hot and cold bathrooms or the facilities around the lakes (Figs 10 and 11). The treatment lounges and landscaping buildings are for both treatment and leisure. Accommodation and public catering are provided by hotels, villas and restaurants. Even if, in the salt spa resorts the author investigated the casino's architectural program (considered to be the most important and indispensable in any resort) is located only in Sovata during the interwar period, the social life of the baths is still intense, the functions of the casino being taken over by other buildings where the therapeutic value is enhanced at the expense of leisure. 

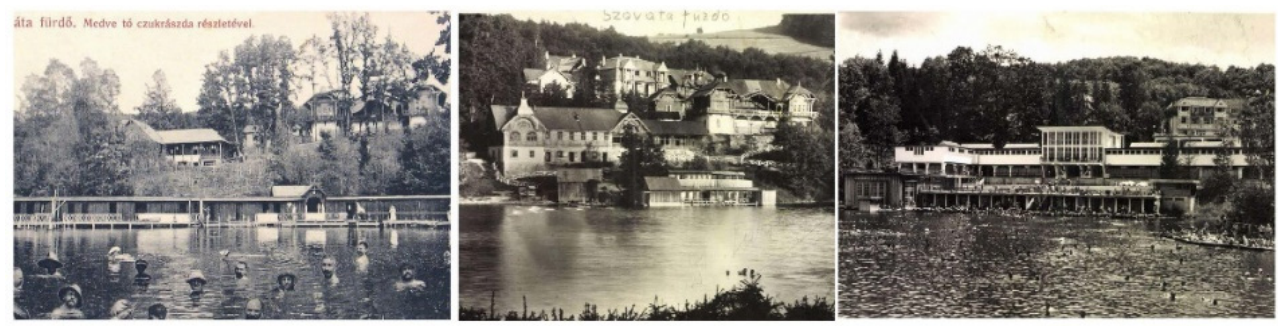

Figure 10: Upper resort main building evolution in Sovata, 1900-1941.
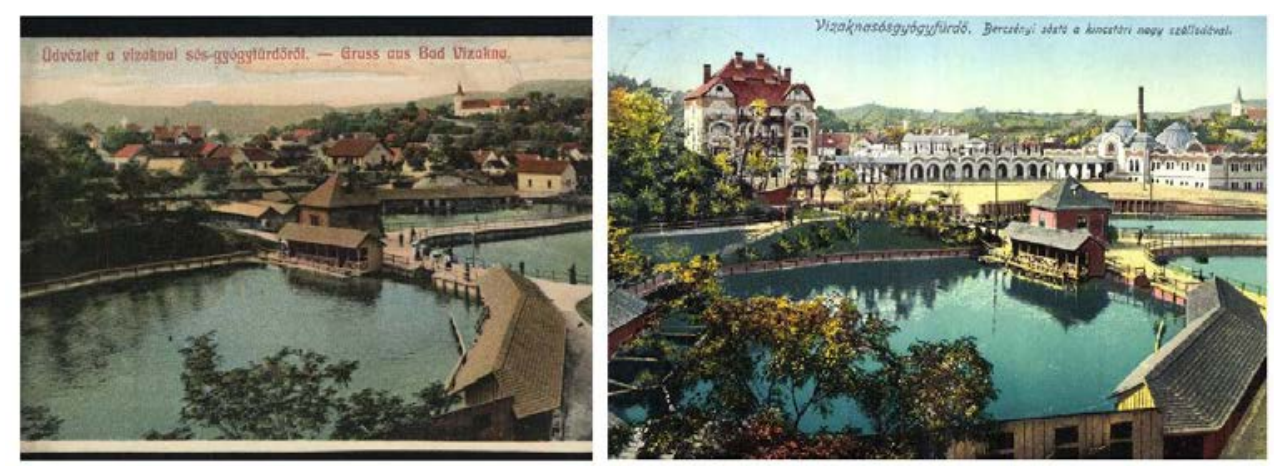

Figure 11: Ocna Sibiu evolution of the resort, 1900-1915.

The architectural program of the park and gardens, both for treatment and for leisure, is always available in the investigated resorts. Thus, in the resort of Ocna Sibiu there are several areas in which parks were set up to serve both the spa area and the locality. The spa area in Sovata includes several parks and playgrounds for children. The park in Ocna Mureş resort, due to its position, is used both by tourists and locals. An extensive park area with a zoo, is situated in the spa area of the Roman Lake in Turda. The historical texts and the postcards show the existence of the parks in the spas of Corund, Bazna, Cojocna, Jabeniţa and Sângeorgiu de Mureş, too. The spa areas of Praid and Ocna Dej do not include parks.

As for the constructive system in the Transylvanian resorts, buildings made of brick or concrete are rarely found, the wooden buildings being more frequent. Paul Petrescu mentions the existence of two types of wooden constructions on the Transylvanian territory: "that of horizontal beams, called Blockbau, and that of a wood-bearing framework filled with various materials called Fachwerk" [16].

The resort in Ocna Sibiu is the only one that has an integrated compound characteristic to the large resorts, and it includes both cold baths with cabins and pavilions around the lakes, hot baths, a treatment parlour and a hotel. The overall volumetry of the warm bath consists of three wings, marked with a corrugated cornice, along which, small flower-shaped fringes are modelled from plaster. The parlour is located southwest of the warm-bath building. The main façade, viewing the lakes, is embellished with a row of arches and pillars and the flat roof was functional as a terrace. The former hotel was built southwest of the parlour, at the foot of the hill. 
For the other resorts, the treatment functions consist of buildings or isolated facilities.

The cold baths are taken in the booths around the lakes, which are built exclusively of wood and are grouped into two types of pavilions. The first type is the perimetral pavilion, like the one in the Lower Sovata resort, Jabenita, Bazna and partially in Ocna Mures. The second type is the isolated pavilion present situated next to the lakes in Turda, the lakes in Sovata's Upper Resort and the lakes in Ocna Sibiu.

The decorative motifs used for the façades of the buildings reflected not only the talent and skill of the craftsmen, but also the social status of the owners. Most of the ornamental motifs originates in the elements that directly influence man's life, bearing magical functions here and there. They are classified into several types, depending on their theme. Thus, there are geometric, phytomorphic, zoomorphic and anthropomorphic ornaments [16].

As a result of the architectural analysis of salt-generated resorts and of the resorts with other particularities, what is more, considering the functions and types of the buildings, it can be seen that these are different, primarily due to the treatment method, which mainly implies taking a bath, usually in lakes, rarely in pools, in wooden booths within perimetral or isolated pavilions. Another type of building, considered to be particularly important for a resort to become popular, is the casino, which is not present in any researched resorts, the only reference about the existence of a casino being in Sovata during the interwar period. The functions of this program are partially overtaken by other buildings in the resort.

Most of the architecture of balneary and touristic buildings in the investigated resorts largely resembles Western trends and style. The treatment is enhanced by endowing the resorts with large parks, which is a consequence of the romantic architecture.

Accommodation is secured in villas and hotels (Fig. 12), whose style is predominantly picturesque, the most striking feature being the balconies, terraces and loges with a view. Since the researched period spans 150 years, besides the picturesque style, which is part of the Romantic style, there are identified aspects of the classical style, Viennese, eclectic and modern secession. As far as the construction system is concerned, brick or concrete buildings are scarce in the Transylvanian resorts, most of them are made of wood.
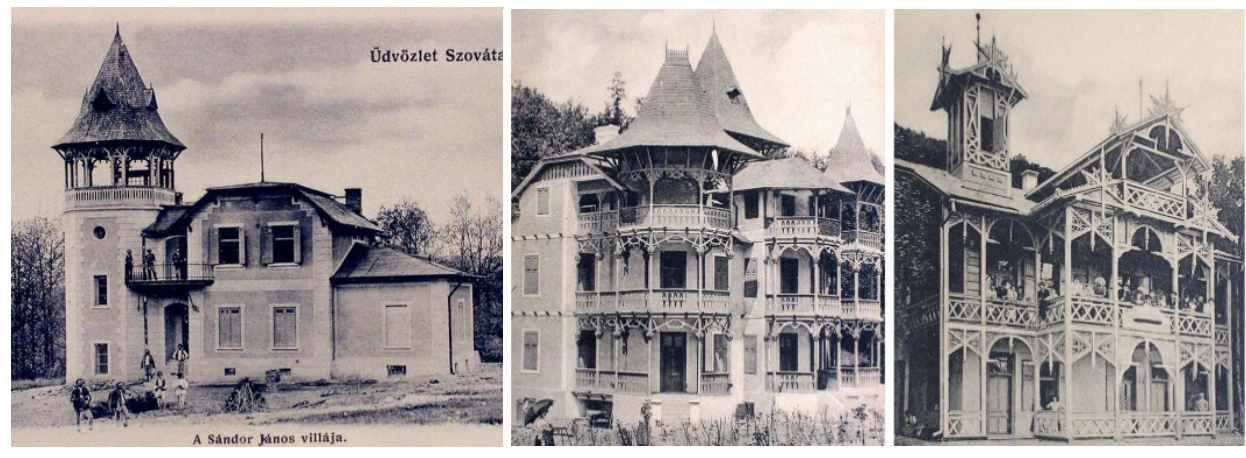

Figure 12: Sovata Villas: Sandor Villa, 1901; Sovata Villa, 1908; Vera Villa, 1909.

\section{CONCLUSIONS}

The cultural heritage concept called the Salt Road is closely related to the connection between salt and salt mining throughout their multimillenary historical development in view of the economic, demographic and territorial impact on the settlements, in comparison with the revenue resulted from the exploited amount of salt and the earned income, to which the 
hydropathic character is added during the modern period which transforms and freshens the cultural tradition of the use of salt in the development of the settlements.

One can notice how salt in its various forms of use can have a powerful impact on the development of the researched towns as the main factor that generates growth. The identity of the towns is, at present, too, defined through the salt deposits and the way they were managed.

Although, from the functional point of view, the constructions comply with certain typologies encountered in all the investigated resorts, it results that the emphasis is laid more on the artistic value of the buildings, by means of which, either different concepts are reflected or the financial situation of the owners, this aspect being most visible in the buildings intended for accommodation or treatment.

The following assertions were also mentioned in the Râmetia Conference: "The years that elapsed with debates and conferences took into account neither the number of architectural monuments that could have been saved, nor the diminution tendency of them. It has already been repeatedly mentioned that it is the last call when people can take action to save the vernacular architectural heritage. It is a fact that vernacular architectural constructions do no longer exist in the traditional, proper meaning of the word and saving them is an increasingly difficult task, because alterations modify them every day, or completely erase them from the face of the earth" [17]. These words are truer than ever as far as the traditional architecture of the villas of the golden age in Sovata is concerned.

Even if the issue of protecting and preserving historical sites has been debated for decades, at least in the case of saltwater spa resorts, little has been done. As a result of the many journeys to the resorts the author took during 2014-2019, and from recent online images research or from Google Street View, I have noticed how the historical heritage is disappearing from year to year. This is the situation in Sovata, where the villas and hotels of the resort, the absolute witnesses of the golden age, wooden built and with traces of the old decorations, are now crumbling. The bath complex in Ocna Sibiu is decayed and battered, a situation found at the Roman Lake in Turda, too. Yet, there is some hope for these resorts since there are still buildings that can be saved. The Ocna Mureş spa resort entirely disappeared, the only remaining elements are the pool for cold baths and the concrete slab in the warm bath pavilion, which still traces of tile finish are still preserved.

The preservation of this heritage is mandatory since it provides an image of the socio-economic and human development of the local and regional communities. The preservation can be performed by means of sustainable and long-lasting development, within which, the communities tie themselves down to the tradition through programs that view culture as a local resource whose main aim is the quality of life.

The author considers that such a research not only contributes scientifically to the study of the Transylvanian spa resorts, but it also is a useful tool when strategic development plans for the area are designed. In areas with salt resources, balneary tourism is the most common form of tourism. Thus, besides elements of cultural or historical value, landscape resources, which, alongside the curative properties of the salty waters, become complementary in the entire valorisation of landscape resources, traditions and salt-related customs.

\section{REFERENCES}

[1] Gheorghe, G., Studii de cultură şi civilizaţie româneascăa, vol. I, Editura Fundaţia Gândirea: Bucureşti, 2001.

[2] Constantiniu, C., Staţiunile balneare ale statului, Tipografia Curţii Regale F., Gobl Fii S.A.: Bucureşti, 1896. 
[3] Vais, G., Clujul eclectic, programe de arhitectură în perioada dualistă (1867-1918), Editura UT Press: Cluj-Napoca, 2009.

[4] Oswald, S., Det Untergang des Abendlandes, vol. II, München, 1923.

[5] Agachi, M.I.M., Clujul modern - aspecte urbanistice, UT Press: Cluj-Napoca, 2009.

[6] Vorona, G.C., Istoria arhitecturii în România, Editura Tehnică: Bucureşti, 1981.

[7] Fundaţia Gândirea, Carpaţii, "solniţa" Europei. http://gandirea.ro/carpatii-solnitaeuropei. Accessed on: 17 Jun. 2019.

[8] Camelia, T., Geomorfositurile pe sare din Depresiunea Transilvaniei şi valorificarea lor turistică, Teză de doctorat, Cluj-Napoca, 2012.

[9] Hajdu, A., Arhitectura de vilegiatură în România modernă, Universitatea de Arte Bucureşti, Facultatea de Istoria Artei, Secţia de Istoria şi Teoria Artei: București, 2012.

[10] László, C., Épülettípusok a kiegyezés utáni Magyarországon, Építésügyi Tájékoztatási Központ: Budapest, 1995.

[11] László, K., Fürdőélet a Monarchiában, Editura Holnap: Kiadó, 1999.

[12] Korunk, http://epa.oszk.hu/00400/00458/00152. Accessed on: 17 Jun. 2019.

[13] Vorona, G.C., Istoria arhitecturii în România, Editura Tehnică: Bucureşti, 1981.

[14] Ionescu, G., Istoria Arhitecturii Românești. Din cele mai vechi timpuri până la 1900, Editura Capitel: București, 2007.

[15] Ștefănut,, A., Arta 1900 în România, Editura Noi Media: București, 2008.

[16] Maier, R.O., Arhitectura țărănească și elementele ei decorative în vestul țării, Editura Comitetul de cultură și educație socialistă al Județului Arad: Arad, 1979.

[17] Ioana, C., Eke Zsuzsanna, Arhitectura vernaculară în regiuni multiculturale, Editura Utilitas: Cluj Napoca, 2009. 